\title{
Spatial Flow and Outflow Distribution in the Una Basin
}

\author{
Aida Korjenić \\ Department of Geography, Faculty of Science, University of Sarajevo, Sarajevo, Bosnia and Herzegovina \\ Email address: \\ aida.k@pmf.unsa.ba

\section{To cite this article:} \\ Aida Korjenić. Spatial Flow and Outflow Distribution in the Una Basin. Hydrology. Vol. 6, No. 2, 2018, pp. 53-60. \\ doi: $10.11648 /$ j.hyd.20180602.12
}

Received: April 27, 2018; Accepted: May 17, 2018; Published: July 4, 2018

\begin{abstract}
The need and importance of studying the water regime in higher and mountainous areas, as well as hypsometric zoning are extremely large in regional and spatial planning. The aspect of spatial regionalization has enabled the understanding of the distribution of water in the basin itself. Based on that, a wider picture of the state of this distribution was obtained in some regional units. Getting involved in solving issues related to gaining values of the river regime's certain elements by hypsometric zones in the Una basin, the basic parameter which it was started from, was determining the value of precipitation amount. For assessment of flow and specific outflow and height, the relation has been applied: precipitation - elevation - area of hypsometric zones - evapotranspiration. Depending on the area they occupy, in the structure of specific outflows and flows, one can clearly distinguish three zones, up to $400 \mathrm{~m}$ altitude, the second hypsometric zone from $400 \mathrm{~m}$ up to $1400 \mathrm{~m}$, and the third zone above $1400 \mathrm{~m}$ altitude. To determine the water height distribution, there have been used the hypsography of the basin and regional specific outflow dependence on average elevation of the basin. Processing all parameters relevant for studying in this paper is done in the ArcGIS software package. The obtained results of this research are very important and can be applied for the needs of agriculture, water management, urbanism and tourism of this part of Bosnia and Herzegovina.
\end{abstract}

Keywords: Flow, Specific Outflow, Precipitation, Hypsometric Zoning, Una, GIS

\section{Introduction}

So far in Bosnia and Herzegovina little work has been done, but also progressed on a more detailed analysis on water height distribution. This imperfection in professional and scientific literature make a large emptiness in hydrologic processing of Bosnian and Herzegovinian rivers. For this very reason, this work has been done by which a scientific contribution was given to better knowledge of hydrologic relations of one of basins in Bosnia and Herzegovina. By analyzing of all current researches related to hydrological characteristics of the Una basin, it can be said that at the beginning, they indicated the insufficient exploration and importance of the influence of certain physical-geographic factors on this river's regime [2]. If you want to get an application approach in solving the problems related to the conductivity of some territory, it is necessary, first of all, to approach a more concrete, qualitative and quantitative analysis of the factors that determine it, as well as an adequate methodological basis $[4,10]$. The aspect of spatial regionalization has enabled the understanding of the distribution of water in the basin itself. The results of hypsometric water zoning have wide application in practice. Particularly significant is the relation between physical geography, but in this context, and hydrographic research and spatial planning [6]. Spatial planning is not possible without a comprehensive analysis of the distribution, quality and quantity of water resources, as one part of the geosystem, and for the purpose of using the overall information accumulated in databases, at all stages of work, from planning to decisionmaking [8].

The Una is a tributary of the Sava, which flows into it at the Jasenovac settlement at a height of $92 \mathrm{~m}$, by which it is counted in the Black Sea basin. The Una River basin extends largely on the territory of Bosnia and Herzegovina, while a smaller area includes a part of the neighboring Republic of Croatia. Towards the surface it covers, $9979.5 \mathrm{~km}^{2}$, hydrographically, the basin can be divided into three large units, and each of them has its own specific characteristics. The lowermost, but largest by size, is the immediate Una basin, which mainly covers the left side of the basin, wellspring part and part at the Una mouth. Its surface area is $4719.4 \mathrm{~km}^{2}$ which is $47.3 \%$ of the basin. The other two, 
significant entities by size, are basins of the Sana and the Unac. The Sana basin is larger, $4356.3 \mathrm{~km}^{2}$, lower and more plenteous with water than the Unac basin which covers 903.8 $\mathrm{km}^{2}$ of the area. Analysis of river system and morphometric indicators were obtained through the work of Arc GIS software, with topographic maps at scale 1:25000. Taking into account all the constant and greatest occasional flows, it has come up to data of the length of the watercourse in the Una basin, which is $10190.6 \mathrm{~km}$. The length of intermittent flows is $6012.8 \mathrm{~km}$, and permanent is $4177.8 \mathrm{~km}$. Measurements of artificial canals were also made which total length was $34.2 \mathrm{~km}$.

\section{Methodology}

Use of empirical formulas or dependencies are the most commonly used methods in hydrology in the absence of surveyed and measured data on river basins. Studying the regime of flows, especially those smaller, unobtrusive ones, is a challenge and need at a time in which witness increasingly exploitation of watercourses. Regional analysis of two or more variable, find more application today and they suppress the classic, obsolete empirical formulas.

The method of outflow dependence on elevation is used for flow breakdown by hypsometric zones, and in that case elementary flow is calculated by form:

$$
Q_{i}=f_{i}\left(h_{i}-h_{i+1}\right) \cdot q_{0}\left(h_{i}-h_{i+1}\right) / 1000
$$

In which $\mathrm{Q}_{\mathrm{i}}$ - flow of appropriate hypsometric zones in $\mathrm{u}$ $\mathrm{m}^{3} / \mathrm{s}, \mathrm{f}_{\mathrm{i}}$ - basin area of the same zone in $\mathrm{km}^{2}$, and $\mathrm{q}_{\mathrm{o}}-$ specific outflow in $1 / \mathrm{s} / \mathrm{km}^{2}$. To calculate this expression, it is necessary beforehand to specify parameters $f$ and $q_{o}$. The sloping surfaces by hypsometric levels per $100 \mathrm{~m}$ were analyzed as well. Parameter $\mathrm{q}_{\mathrm{o}}-$ specific outflow or specific basin bounty comes from dependencies $\mathrm{q}_{\mathrm{o}}=\mathrm{f}\left(\mathrm{H}_{\mathrm{av}}\right)$.

The second method in determining hypso-hydrography of the basin is based on construction of isolines of specific outflow on the maps on which isohypses were presented too. It is cartographic method of hypsometric zoning of waters built in ArcGIS program. By calculating the surface between the isolines, the water height distribution is determined.

Determining the values and variability of flow and specific outflow relied on use of precipitation data from the net of meteorology stations in the basin. The data from 17 meteorology stations on different elevations was analyzed, and during the period 1961-1990, three different methods were used: Arithmetic Mean, Thiessen polygons and Isohyetal method. Connection between precipitation and elevation was determined on the basis of linear correlation. It was noticed by analyze that annual amount of precipitation in the Una basin increases for $47.7 \mathrm{~mm}$ per every $100 \mathrm{~m}$ [1].

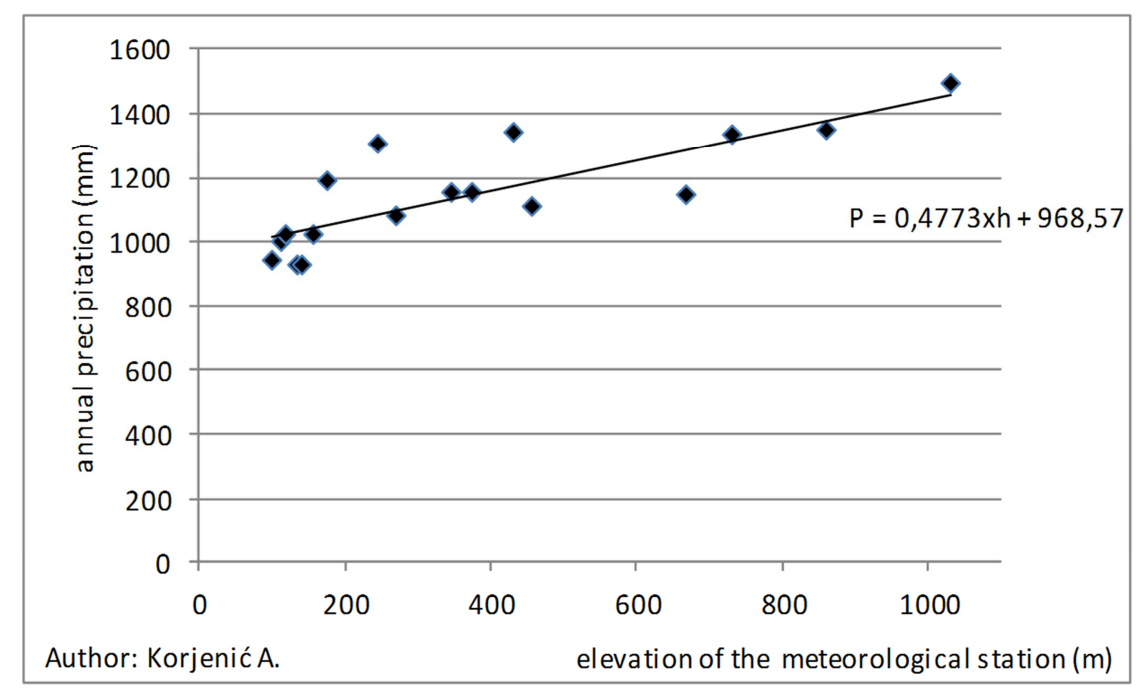

Figure 1. Regression direction chart (elevation and precipitation ratio) in the Una basin.

Specific outflow was defined by relation: precipitation elevation - type of rocks, so for these needs, also lithological-hydrological complex in the basin was analyzed. Types of rocks and their hydro-geological characteristics were analyzed in sense of their permeability. It was approached from many aspects to analysis of specific outflows. Above all, from aspect of water height regionalization [2, 4, 5], where a need is imposed to determine the quantity and distribution of waters per altitude zones, and percentage participation of altitude zones in forming the whole outflow as well. The second aspect of analysis of specific outflows is related to their height distribution in dependence of altitude representation of certain lithological - hydrological complexes.

\section{Result and Discussion}

Flow disposition by hypsometric zones in the Una basin was calculated by the available amount of water over individual zone area per time unit. Average annual precipitation sums are from $875 \mathrm{~mm}$ in the mouth of the Una into the Sava, to over $1800 \mathrm{~mm}$ at the highest mountain peaks. The most part of the basin is placed inside isohyets from 900 up to $1100 \mathrm{~mm}$ (river valleys of the Una, Sana, 
valleys and hills). Morpho structures above $500 \mathrm{~m}$ altitude have also larger amount of precipitation, on average over 1 $200 \mathrm{~mm}$, while areas above $1000 \mathrm{~m}$ altitude receive over 1 $400 \mathrm{~mm}$ per year. Effective precipitation (Pef) in Una River basin determined according to the author's previous research [3].

\subsection{Types of Aquifers}

For analysis of flow and specific outflow as particularly important, participation of individual lithological hydrological complexes is secluded, means types of aquifers, in every observed hypsometric zone. These analyzes were carried out according to research Žigić, Skopljak, Hrvatović, Pašić-Škripić [7].

Water permeability of rocks directly influences on water inflow in streams from every altitude zone, and then to total participation in the Una flow. It can be stated that the largest share, in the territory of the Una basin, belongs to well pervious rocks with $66.4 \%$, then come the impervious ones with $27.9 \%$, while semi-pervious to impervious have the smallest participation in the area, only 5.7\% [9].

Table 1. Percentage participation of types of aquifers by hypsometric zones.

\begin{tabular}{lllll}
\hline Aquifer type & $\begin{array}{l}\text { Aquifers of intergranular } \\
\text { porosity }\end{array}$ & Aquifers of crevice porosity & $\begin{array}{l}\text { Aquifers of crevice -cavern } \\
\text { porosity }\end{array}$ & $\begin{array}{l}\text { Hydrogeologic complexes } \\
\text { mostly without aquifers }\end{array}$ \\
\hline $0-100$ & 0.00 & 0.00 & 1.26 & 1.90 \\
$100-200$ & 4.14 & 13.96 & 16.95 & 52.49 \\
$200-300$ & 10.27 & 30.94 & 19.03 & 11.38 \\
$300-400$ & 28.16 & 32.53 & 10.81 & 2.64 \\
$400-500$ & 34.19 & 25.46 & 9.50 & 1.22 \\
$500-600$ & 36.03 & 19.90 & 7.49 & 3.24 \\
$600-700$ & 39.58 & 17.85 & 2.64 & 3.13 \\
$700-800$ & 53.28 & 13.91 & 3.20 & 1.26 \\
$800-900$ & 52.89 & 13.27 & 2.28 & 2.69 \\
$900-1000$ & 52.13 & 15.05 & 1.17 & 0.20 \\
$1000-1100$ & 54.19 & 12.54 & 1.40 & 0.21 \\
$1100-1200$ & 51.71 & 8.91 & 1.99 & 0.13 \\
$1200-1300$ & 51.83 & 9.46 & 1.02 & 0.00 \\
$1300-1400$ & 46.76 & 4.67 & 0.49 & 0.00 \\
$1400-1500$ & 41.04 & 3.68 & 0.06 & 0.00 \\
$1500-1600$ & 32.68 & 2.11 & 0.00 & 0.00 \\
$1600-1700$ & 26.33 & 1.74 & 0.00 & 0.00 \\
$1700-1800$ & 36.31 & 1.55 & 0.00 & 0.00 \\
$1800-1900$ & 18.03 & 0.00 & 0.00 & 0.00 \\
$1900-2000$ & 0.00 & 0.00 & 0.00 & \\
\hline
\end{tabular}

Table 1. Continued.

\begin{tabular}{|c|c|c|c|}
\hline Aquifer type & $\begin{array}{l}\text { Hydrogeologic complexes with } \\
\text { aquifers of composite porosity }\end{array}$ & Highly karstic aquifers & $\begin{array}{l}\text { Non-water-bearing rocks (aquitards) } \\
\text { without aquifers }\end{array}$ \\
\hline $0-100$ & 96.84 & 0.00 & 0.00 \\
\hline $100-200$ & 7.94 & 0.03 & 4.49 \\
\hline $200-300$ & 12.63 & 0.79 & 14.96 \\
\hline $300-400$ & 12.63 & 0.50 & 12.73 \\
\hline $400-500$ & 17.40 & 0.44 & 11.79 \\
\hline $500-600$ & 28.18 & 0.72 & 4.44 \\
\hline $700-800$ & 25.90 & 0.49 & 0.11 \\
\hline $800-900$ & 28.00 & 2.29 & 0.01 \\
\hline $900-1000$ & 26.20 & 2.76 & 0.00 \\
\hline $1000-1100$ & 26.19 & 5.48 & 0.00 \\
\hline $1100-1200$ & 29.80 & 7.38 & 0.00 \\
\hline $1200-1300$ & 33.42 & 4.14 & 0.00 \\
\hline $1300-1400$ & 44.89 & 3.19 & 0.00 \\
\hline $1400-1500$ & 51.78 & 3.44 & 0.00 \\
\hline $1600-1700$ & 71.93 & 0.00 & 0.00 \\
\hline $1700-1800$ & 62.14 & 0.00 & 0.00 \\
\hline $1800-1900$ & 81.97 & 0.00 & 0.00 \\
\hline $1900-2000$ & 100.00 & 0.00 & 0.00 \\
\hline
\end{tabular}

This kind of hydro-geological relations in the basin has influenced on forming surface river network, and on large bounty of sources and springs, as well. In zone that includes the largest areas in the basin 200-300 m, aquifers of cracking porosity are the most common which are poorly pervious to impervious. Beside them, as impervious hydrogeological complexes are stated predominantly without aquifers and aquitards, which makes about $57 \%$ of area of this zone in 
total, that causing a larger surface water network and greater surface inflow in streams from this hypsometric level. Similar relations, with different participations of impervious aquifers, are in zones from 100 to $200 \mathrm{~m}$, and from 300 to $400 \mathrm{~m}$, which together make about $40 \%$ of the basin area. Intergranular porosity aquifers and hydrogeological complexes with mixed porosity aquifers which are characterized by good water permeability dominate in all zones in the area above $400 \mathrm{~m}$ altitude. Since this is about almost $60 \%$ of total surface area of the basin and about favorable conditions for recharging aquifers with water, it is possible to form bodies of groundwater with high bounty.

\subsection{Analysis Flow of the Una River}

The Una basin average flow obtained through dependence $\mathrm{Q}=\mathrm{qF} / 1000$ is $232.5 \mathrm{~m}^{3} / \mathrm{s}$.

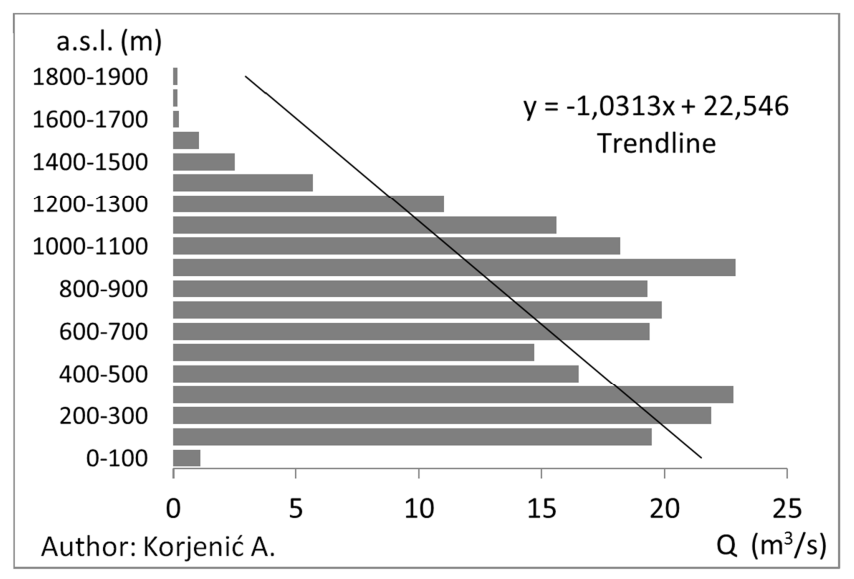

Figure 2. Hypso-hydrogram of flow (Q).

According to measurements and observations, in watermeter station, at the mouth of the Una into the Sava in Bosanska Dubica, average annual flow for perennial period
(1961-1990) amounts $\mathrm{Q}=238 \mathrm{~m}^{3} / \mathrm{s}$.

It is noted by analysis that with increasing of the basin's surface, flows increase as well. Considering the small surface of individual zones, irrespective of the basin wealth, flows are small, so for example on heights 1800-1900 m. Zone from 300-400 m, gives uppermost of the flows, although the largest catchment has the basin area at height of 200-300 m. The flows are reduced with height increasing, but in aforementioned zone the larger flow is influenced by the larger basin bounty, but only slightly smaller area of the previous zone.

Summarized review of waters by hypsometric zones shows that above $600 \mathrm{~m}$ (average height of the basin $598 \mathrm{~m}$ ), 135.93 $\mathrm{m}^{3} / \mathrm{s}$ flows are formed, or $58.5 \%$ of the total waters of the Una basin.

On hypso-hydrographic flow curve, two types of water differ: autochthonous and overall (autochthonous and transit). So, for example, for the zone of 200-300 m, autochthonous flow Qau $=21.9 \mathrm{~m}^{3} / \mathrm{s}$, transit Qtr $=189.83$ $\mathrm{m}^{3} / \mathrm{s}$, while the total $\mathrm{Q}$ above isohypse of $200 \mathrm{~m}$ is equal $211.8 \mathrm{~m}^{3} / \mathrm{s}$. Flow above appropriate isohypse is equal to sum of higher hypsometric zones flows.

If the flow rate is analyzed per hypsometric zones over the larger Una sub-basins (the immediate Una basin, the Sana and the Unac) it can be concluded that in the total Una flow the largest share belongs to the Sana basin. This sub-basin by area is not the largest but receives about $1300 \mathrm{~mm}$ precipitation annually, so in the Una flow it participates with $103.2 \mathrm{~m}^{3} / \mathrm{s}$. The slight difference in the flow between the Sana and the immediate Una basin, about $5 \mathrm{~m}^{3} / \mathrm{s}$, comes from a slightly smaller amount of precipitation, but also from larger area of the immediate Una basin. The least but considerably, participation in the Una flow has the Unac basin, $31.5 \mathrm{~m}^{3} / \mathrm{s}$. The reason for this is smaller area of the Unac basin, but also pluviometric regime of this part of basin.

Table 2. Flows $(Q)$ and specific outflows (q) according to effective precipitation (Pef), by hypsometric zones.

\begin{tabular}{|c|c|c|c|c|c|}
\hline Hypsometric zones & Area of zone $\left(\mathrm{m}^{2}\right)$ & Total precipitation $\left(\mathrm{m}^{3}\right)$ & $\mathrm{Q}\left(\mathrm{m}^{3} / \mathrm{s}\right)$ & $\Sigma Q\left(m^{3} / s\right)$ & $\mathrm{q}\left(\mathrm{l} / \mathrm{s} / \mathrm{km}^{2}\right)$ \\
\hline $1800-1900$ & 1000000 & 1510200 & 0.05 & 0.05 & 50.0 \\
\hline $1700-1800$ & 2000000 & 2900200 & 0.09 & 0.14 & 45.0 \\
\hline $1600-1700$ & 4990000 & 6863246 & 0.22 & 0.36 & 44.1 \\
\hline $1500-1600$ & 24950000 & 33166035 & 1.05 & 1.41 & 42.1 \\
\hline $1400-1500$ & 60880000 & 77427184 & 2.5 & 3.91 & 41.1 \\
\hline $1300-1400$ & 148710000 & 180162165 & 5.7 & 9.61 & 38.3 \\
\hline $1200-1300$ & 302410000 & 347590054 & 11.02 & 20.63 & 36.4 \\
\hline $1000-1100$ & 558900000 & 575108100 & 18.2 & 54.43 & 32.6 \\
\hline $900-1000$ & 755520000 & 725072544 & 22.9 & 77.33 & 30.3 \\
\hline $800-900$ & 674680000 & 607549340 & 19.3 & 96.63 & 28.6 \\
\hline $700-800$ & 749530000 & 629380341 & 19.9 & 116.53 & 26.5 \\
\hline $600-700$ & 785460000 & 610223874 & 19.4 & 135.93 & 24.7 \\
\hline $500-600$ & 633760000 & 462644800 & 14.7 & 150.63 & 23.2 \\
\hline $400-500$ & 781470000 & 518974227 & 16.5 & 167.13 & 21.1 \\
\hline $200-300$ & 1374310000 & 690728206 & 21.9 & 211.83 & 15.9 \\
\hline $100-200$ & 1373310000 & 616478859 & 19.5 & 231.33 & 14.2 \\
\hline $0-100$ & 86830000 & 34732000 & 1.1 & 232.43 & 12.7 \\
\hline Una River basin & & & 232.5 & & 23.3 \\
\hline
\end{tabular}




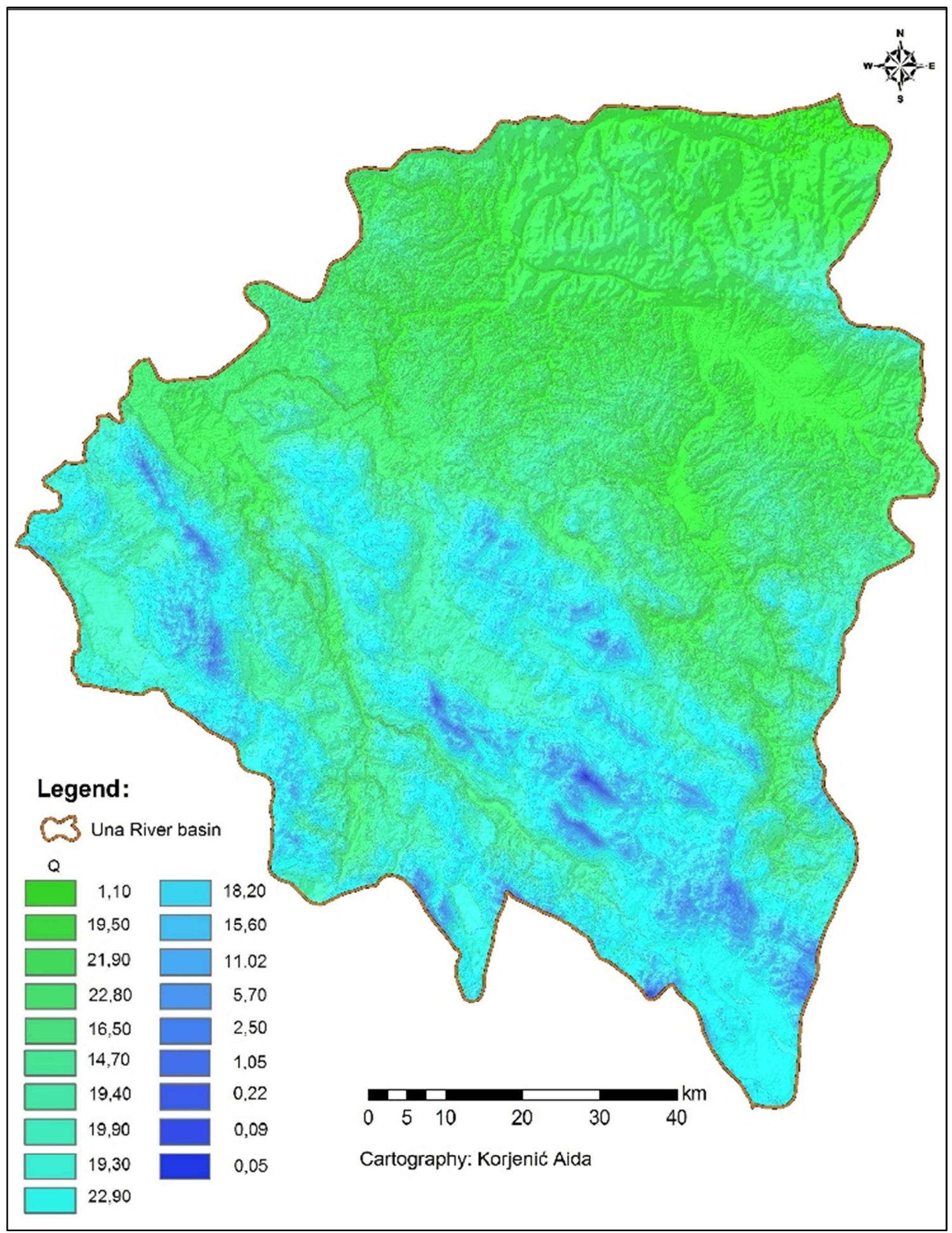

Figure 3. Flow rate (Q) by hypsometric zones $\left(\mathrm{m}^{3} / \mathrm{s} / 100 \mathrm{~m}\right)$.

\subsection{Analysis Specific Outflow of the Una River}

Average specific outflow for the Una basin according to obtained flow, amounts $23.3 \mathrm{l} / \mathrm{s} / \mathrm{km}^{2}$. At the base of calculation, it could be concluded that specific bounty of the basin decreases from the highest to the lowermost elevation. According to that, with decreasing amount of precipitation, the value of specific outflow is decreased. It decreases nonlinearly (Table 2).
The same relations are represented in the sub-basins also, where specific outflow decreases from the highest to the lowermost hypsometric levels (Table 3). Differences, which are spotted in the flow and specific outflow among subbasins in the same hypsometric zones, are the result of different surfaces of these zones by sub -basins, as well as precipitation increase coefficient, which was taken into account during calculating the precipitation amount. 
Although the gradient of specific outflow is increased nonlinearly, in average for $1.99 \mathrm{l} / \mathrm{s} / \mathrm{km}^{2}$ per every $100 \mathrm{~m}$, its changes are not the same at all heights. There is a steady increase in zones between $400 \mathrm{~m}$ and $1400 \mathrm{~m}$, while beneath $400 \mathrm{~m}$ and above $1400 \mathrm{~m}$ those changes are uneven (larger or smaller than the average).

Concerning the asymmetry of water hypsometric distribution (in relation to average basin elevation), evaporation, relief slope and relief energy of the basin show significant influence on its bounty. Beside these aforementioned physical - geographical factors, outflow is affected by air temperature, winds, humidity, but also afforestation and geological structure.

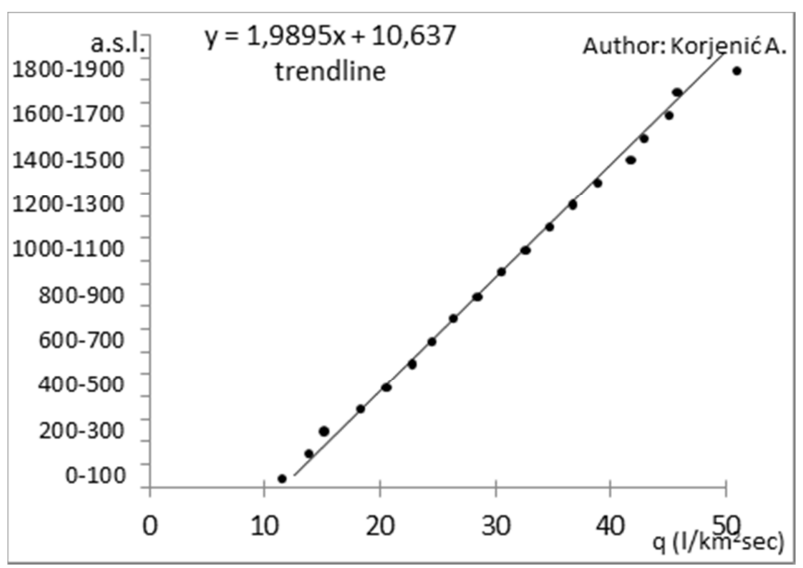

Figure 4. Dependence of specific outflow and hypsometric zones.

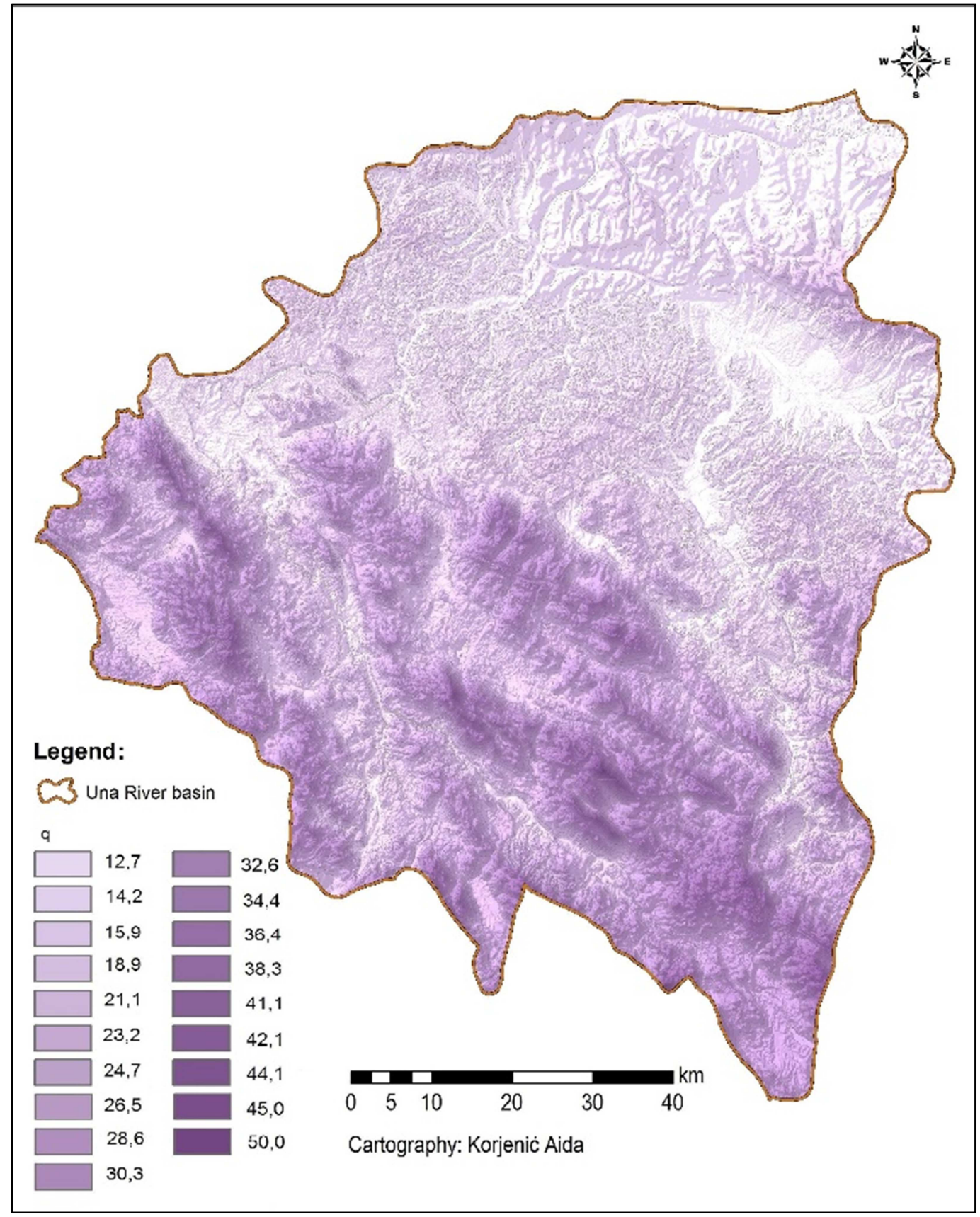

Figure 5. Specific outflow by hypsometric zones $\left(l / \mathrm{s} / \mathrm{km}^{2} / 100 \mathrm{~m}\right)$. 
Table 3. Flows $(Q)$ and specific outflows $(q)$ in larger Una sub-basins by hypsometric zones.

\begin{tabular}{|c|c|c|c|c|c|c|}
\hline \multirow[b]{2}{*}{ Hypsometric zones } & \multicolumn{2}{|c|}{ Direct Una River basin } & \multicolumn{2}{|c|}{ Sana River system } & \multicolumn{2}{|c|}{ Unac River system } \\
\hline & $\mathrm{Q}\left(\mathrm{m}^{3} / \mathrm{s}\right)$ & $\mathrm{q}\left(\mathrm{l} / \mathrm{s} / \mathrm{km}^{2}\right)$ & $\mathrm{Q}\left(\mathrm{m}^{3} / \mathrm{s}\right)$ & $\mathrm{q}\left(\mathrm{l} / \mathrm{s} / \mathrm{km}^{2}\right)$ & $\mathrm{Q}\left(\mathrm{m}^{3} / \mathrm{s}\right)$ & $\mathrm{q}\left(\mathrm{l} / \mathrm{s} / \mathrm{km}^{2}\right)$ \\
\hline $0-100$ & 0.77 & 12.65 & & & & \\
\hline $100-200$ & 5.2 & 14.29 & 1.70 & 15.10 & & \\
\hline $200-300$ & 13.4 & 15.82 & 7.58 & 15.23 & & \\
\hline $300-400$ & 4.9 & 16.91 & 9.38 & 16.88 & 0.04 & 25.18 \\
\hline $400-500$ & 8.9 & 19.12 & 11.04 & 19.35 & 0.65 & 27.16 \\
\hline $500-600$ & 13.1 & 20.02 & 7.12 & 20.54 & 1.39 & 29.04 \\
\hline $700-800$ & 10.1 & 22.06 & 7.48 & 24.73 & 3.90 & 32.09 \\
\hline $800-900$ & 9.6 & 26.34 & 9.97 & 26.84 & 2.72 & 33.81 \\
\hline $900-1000$ & 7.3 & 28.07 & 11.28 & 29.06 & 2.48 & 35.47 \\
\hline $1000-1100$ & 6.4 & 30.40 & 10.78 & 31.17 & 3.69 & 37.46 \\
\hline $1100-1200$ & 3.6 & 31.78 & 11.76 & 33.24 & 3.10 & 39.02 \\
\hline $1200-1300$ & 1.3 & 32.79 & 5.88 & 35.90 & 2.88 & 40.85 \\
\hline $1300-1400$ & 0.8 & 37.66 & 1.91 & 36.58 & 2.32 & 42.61 \\
\hline $1400-1500$ & 0.4 & 40.35 & 0.69 & 42.69 & 1.01 & 44.31 \\
\hline $1600-1700$ & 0.02 & 42.37 & & & 0.25 & 47.17 \\
\hline $1700-1800$ & & & & & 0.14 & 49.32 \\
\hline $1800-1900$ & & & & & 0.06 & 51.02 \\
\hline
\end{tabular}

South and south-east part of the basin was developed in area with karst domination or where there is disagreement between the surface and the underground watershed.

\section{Conclusions}

Depending on the area they occupy, in the structure of specific outflows and flows, one can clearly distinguish three zones. The first zone is an area up to $400 \mathrm{~m}$ altitude, where specific outflow is $20 \mathrm{l} / \mathrm{s} / \mathrm{km}^{2}$. It is a space which includes $40.5 \%$ of the total basin area on which total flow is formed of $65.3 \mathrm{~m}^{3} / \mathrm{s}$ or $28.1 \%$. In this zone, in which excreted about $28 \%$ of the total precipitation quantity, the most represented are crack porosity aquifers that are poorly pervious to impervious, as well as water impervious hydro-geology complexes predominantly without aquifers.

This imposes a larger surface water network and greater surface inflow in streams from areas up to $400 \mathrm{~m}$. The second hypsometric zone, from $400 \mathrm{~m}$ up to $1400 \mathrm{~m}$, includes $58.6 \%$ of territory of the basin, with average annual specific outflows of $20-40 \mathrm{l} / \mathrm{s} / \mathrm{km}^{2}$ and sum of flow which is $163.2 \mathrm{~m}^{3} / \mathrm{s}$, that makes $70 \%$ from the total flow. In the area above $400 \mathrm{~m}$ altitude, about $72 \%$ of the total precipitation amount was disposed over all zones. In hydrogeological view, intergranular porosity aquifers dominate mostly as well as hydro-geological complexes with mixed porosity aquifers which are distinguished with good water permeability. Of the total area of the Una basin, only $0.9 \%$ belong to the third belt, zone above $1400 \mathrm{~m}$ with specific outflows larger than $40 \mathrm{l} / \mathrm{s} / \mathrm{km}^{2}$ and the lowest total flow of just $3.91 \mathrm{~m}^{3} / \mathrm{s}$ or $1.9 \%$. The model applied in this work has been checked out to the profile in Bosanska Dubica with data for 30 -year period. In this way it is possible to distribute the flow and the specific outflow according to territory of the basin depending on relevant physical-geographic parameters.

\section{References}

[1] A. Korjenić, E. Temimović, A. Banda, and Sivac, A., "Basic Characteristics of The Pluviometric Regime in The Una River Basin", International Journal of Research - Granthaalayah, 6 (2), pp. 234-245, 2018.

[2] A. Korjenić, "The Una River - physical-geographical conditions of hypsometric zoning waters in the basin", doctoral dissertations, Sarajevo: Faculty of Science, Department of Geography, University of Sarajevo, 2015, pp. 38 .

[3] A. Korjenić, "Isohyet and evapotranspiration elements in wather regime of the river Una", Acta geographica Bosniae et Herzegovinae, Vol. 1, No. 1, Sarajevo: Association of Geographers in B\&H, pp. 114-123, 2014.

[4] S. Mustafić, "Spatial Distribution of Runoff in Temstica River Basin", Beograd: Bulletin of The Serbian Geographical Society, Vol. LXXXVI - No 2, pp. 45-52.

[5] M. Ocokoljić, "Height zoning water in the basin of the Velika Morava and some aspects of their protection", Special edition, Vol. 64, Beograd: Serbian Geographical Society, 1987.

[6] Y. M. Semenov, "Landscape planning: The applied branch in complex physical geography", Geography and Natural Resources, Vol. 38, No. 4, Pleiades Publishing, Ltd., 2017, pp. 319-323.

[7] I. Žigić, F. Skopljak, H. Hrvatović, D. Pašić-Škripić, "Hydrogeological regionization of the terrain in the Una River Basin on the territory of the Federation of Bosnia and Herzegovina", Proceedings book, Tuzla: Faculty of Mining and Geology, University of Tuzla, 2010.

[8] M. F. Rahaman, C. S. Jahan, R. Arefin, Q. H. Mazumder, "Morphometric Analysis of Major Watersheds in Barind Tract, Bangladesh: A Remote Sensing and GIS - Based Approach for Water Resource Management”, Hydrology. Vol. 5, No. 6, 2017, pp. 86-95. doi: 10.11648/j.hyd.20170506.12. 
[9] A. Korjenić, A. Sivac, Š. Okerić, "Geological Characteristics and Density of the Una Water System as a Factor of Spatial Planning, B\&H", Journal of International Environmental Application \& Science, Vol. 12, No. 1, pp. 63-72, 2017.
[10] A. Korjenić, S. Herenda, "The influence of Geological Field Structure on Water Quality in the Selected Source of the Ljubija Area, B\&H”, Journal of International Environmental Application \& Science, Vol. 11, No. 2, pp. 180-185, 2016. 